\title{
UNLIKELY
}

2

E

o

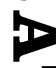

ב

1

0

4

GENDER AND CULTURE SERIES 


\section{GENDER AND CULTURE}

A SERIES OF COLUMBIA UNIVERSITY PRESS

Nancy K. Miller and Victoria Rosner, Series Editors

Carolyn G. Heilbrun (1926-2003) and

Nancy K. Miller, Founding Editors 


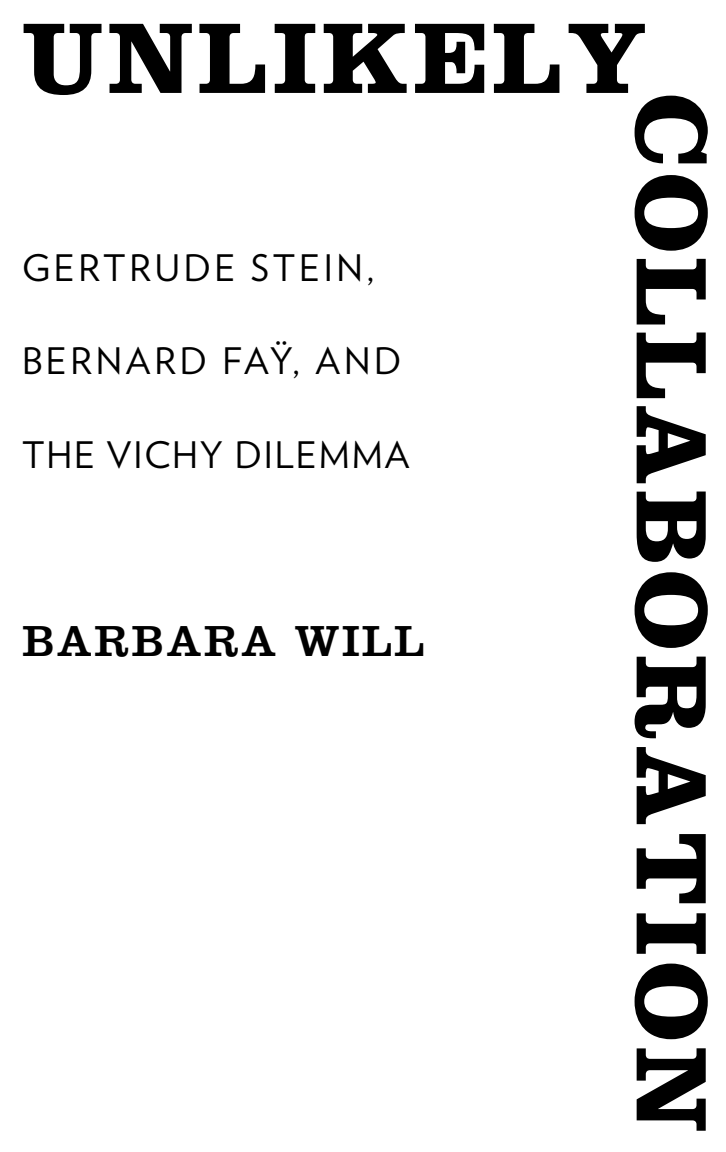

Columbia University Press $\mathbf{n}$ New York 


\section{COLUMBIA UNIVERSITY PRESS}

Publishers Since 1893

New York Chichester, West Sussex

Copyright (C) 2011 Columbia University Press

Paperback edition, 2013

All rights reserved

Library of Congress Cataloging-in-Publication Data

Will, Barbara

Unlikely collaboration : Gertrude Stein, Bernard Faÿ, and the Vichy dilemma / Barbara Will.

p. cm. - (Gender and culture)

Includes bibliographical references and index.

ISBN 978-0-231-15262-4 (cloth : alk. paper)-

ISBN 978-0-231-15263-1 (pbk. : alk. paper)-

ISBN 978-o-231-52641-8 (e-book)

1. Stein, Gertrude, 1874-1946-Friends and associates. 2. Faÿ,

Bernard, 1893-- Friends and associates. 3. Politics and literature-France-History-2oth century. 4. FranceIntellectual life-2oth century. I. Title. II. Series.

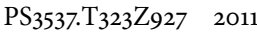

$818^{\prime} .5209-\mathrm{dc} 22$

[B]

2011013191

Columbia University Press books are printed on permanent and durable acid-free paper.

Printed in the United States of America

Book design by Lisa Hamm

Cover image courtesy of the Beinecke Rare Book and

Manuscript Library

Cover design by Noah Arlow

c 10987654321

p 10987654321 
FOR MICHAEL

Verweile doch

$\infty$ 
